\title{
Implementasi Metode PERT dan CPM pada Sistem Informasi Manajemen Proyek Pembangunan Kapal
}

\author{
Abdurrasyid*, Luqman, Abdul Haris, Indrianto \\ Program Studi Sarjana Teknik Informatika \\ Sekolah Tinggi Teknik PLN \\ Jakarta \\ *arasyid@sttpln.ac.id
}

\begin{abstract}
Abstrak-Ketepatan waktu, biaya, dan kualitas adalah hal yang menjadi perhatian dalam perencanaan proyek yang tertuang dalam penjadwalan proyek. Dalam pengerjaan proyek muncul beberapa masalah dalam perencanaan dan pengendalian proyek, yaitu sulitnya dipetakan jalur kritis dari suatu kegiatan. Pada PT. Bandar Abadi keterlambatan proyek sering terjadi akibat tertundanya penyelesaian kegiatan-kegiatan kritis dan berimbas pada biaya proyek semakin besar. Pada penelitian ini digunakan metode Critical Path Method (CPM) dan Project Evaluation Review Technic (PERT) yang digunakan membantu project manager dalam merencanakan dan mengendalikan proyek, di mana metode ini dapat membantu project manager dalam menentukan kegiatan kritis dan mengetahui estimasi waktu penyelesaian pada sebuah proyek. Hasil akhir yang didapatkan dalam penelitian ini adalah didapatkannya jalur kritis untuk pembangunan kapal dilengkapi dengan sistem informasi berbasis web yang dapat digunakan project manager untuk mengelola proyek pembangunan kapal dengan menggunakan metode PERT dan CPM, dapat membantu dalam mengelola proyek pembangunan kapal di PT. Bandar Abadi, menurunkan risiko keterlambatan proyek, dan mencegah munculnya biaya proyek akibat keterlambatan.
\end{abstract}

Kata kunci: Estimasi, Jalur Kritis, Manajemen Proyek, Penjadwalan, PERT \& CPM

\section{Pendahuluan}

Suatu kegiatan proyek dapat dikatakan berhasil apabila semua ruang lingkup pekerjaan terpenuhi dengan kualitas yang baik, kesesuaian antara realisasi jadwal, biaya yang dikeluarkan, serta batasan waktu yang telah disepakati [1]. Oleh karena itu, sangat diperlukan penggunaan waktu yang efisien dan efektif. Pengetahuan dan kemampuan yang cukup dalam menggunakan tools yang biasa digunakan dalam manajemen proyek seperti Microsoft project, excel, primavera, dan lain-lain menjadi modal yang harus dimiliki seorang project manager khususnya pemula [2]. Kemampuan ini akan semakin lengkap apabila seorang project manager dibantu dengan aplikasi pendukung manajemen proyek. Kemampuan ini mempermudah project manager dalam mengelola dan mendokumentasikan, baik itu proyek skala kecil atau pun besar juga dapat memangkas waktu monitoring karena cukup melihat dari sistem. Selama ini perusahaan dalam menentukan waktu hanya berdasarkan pengalaman sehingga beberapa masalah sering muncul dalam perencanaan dan pengendalian proyek yaitu lengahnya manajer proyek dalam memetakan jalur kritis dari suatu kegiatan. Jalur kritis sangat penting bagi pelaksanaan proyek. Pada PT. Bandar Abadi keterlambatan proyek sering terjadi akibat tertundanya penyelesaian kegiatan-kegiatan kritis dan berimbas pada biaya proyek semakin besar. Kadang dijumpai lebih dari satu jalur kritis dalam kegiatan pengerjaan proyek.
PT. Bandar Abadi adalah perusahaan yang bergerak dalam bidang pembangunan kapal. Permasalahan yang sering muncul adalah ketidaksesuaian antara target waktu dengan realisasi penyelesaian sehingga berdampak pada biaya yang dikeluarkan semakin membengkak, berimbas pada keuntungan yang didapatkan perusahaan, bahkan perusahaan bisa mengalami kerugian akibat pinalti yang harus dipenuhi apabila proyek pembuatan kapal tidak sesuai dengan waktu yang telah disepakati. Peralatan produksi yang tidak memadai, pengadaan material yang dibutuhkan, pengadaan dan kualitas sumber daya manusia, serta biaya menjadi beberapa faktor yang dapat mempengaruhi waktu penyelesaian proyek [3], keterlambatan akan berimbas tidak hanya pada biaya, tetapi juga pandangan konsumen akan kredibilitas perusahaan itu sendiri yang akan berdampak pada kelangsungan hidup perusahaan.

Dalam perencanaan dan pengendalian proyek, salah satu metode yang digunakan adalah metode PERT (Project Evaluation and Review Technique) dan CPM (Critical Path Method-Metode Jalur Kritis). Kedua metode ini merupakan metode yang cukup banyak digunakan dalam perencanaan dan pengendalian proyek seperti proyek jembatan girder [4] di mana masalah terletak pada timeframe proyek yang dapat diselesaikan sesuai dengan pergeseran waktu ditetapkan pada 42 hari di awal, untuk 35 hari, selain itu metode ini digunakan pada proyek pembangunan fasilitas rumah karyawan [5]. Metode ini memiliki kelebihan untuk menganalisis proyek dari segi memperkirakan 
waktu penyelesaian proyek dengan mencari jalur kritis, mengidentifikasi awal dan akhir waktu setiap kegiatan untuk mencari jadwal proyek, dan menghitung jumlah waktu slack untuk setiap kegiatan sehingga mampu meminimalisasi keterlambatan proyek [6]. Kekurangan yang ada pada penelitian-penelitian sebelumnya termasuk yang diutarakan pada kajian pustaka adalah perhitungan metode PERT dan CPM masih dilakukan secara manual dan metode PERT dan CPM belum diterapkan pada proyek pembangunan kapal.

Pada metode PERT dan CPM (Critical Path Method) terdapat tahapan penentuan jalur kritis, di mana jalur kritis merupakan kegiatan-kegiatan dalam proyek yang memiliki total jumlah waktu terlama dan menunjukkan rentang waktu penyelesain proyek yang tercepat [1].

Dengan diterapkan metode PERT dan CPM pada aplikasi, khususnya pada proyek pembangunan kapal, dapat membantu dan mempermudah project manager dalam melakukan pemetaan masalah dalam pengerjaan proyek sehingga waktu dan biaya yang dibutuhkan dalam pengerjaan proyek dapat diestimasi dengan baik dan jalur kristis dalam pengerjaan proyek dapat dipetakan dengan baik. Manajer proyek juga mudah mengetahui kegiatankegiatan kritis dalam pengerjaan proyek sehingga kegiatan tersebut lebih perlu dikendalikan agar kegiatan yang berhubungan tidak mengalami keterlambatan dan proyek bisa diselesaikan dalam tepat waktu.

\section{Kajian Pustaka}

\section{a. Penelitian Terdahulu}

Penelitian yang menerapkan metode PERT dan CPM pernah dilakukan untuk membandingkan analisis penjadwalan yang dibuat CV. Catur Tunggal berdasarkan data time schedule dengan metode CPM. Setelah dibandingkan antara perhitungan yang dibuat dengan menggunakan metode CPM dan hasil perhitungan CV. Catur Tunggal, menunjukkan bahwa perhitungan dengan metode CPM lebih menguntungkan, di mana proyek dapat selesai selama 135 hari sedangkan berdasarkan data jadwal waktu penyelesaian proyek tersebut adalah 150 hari sehingga perhitungan dengan mengggunakan metode CPM dapat memangkas waktu penyelesaian proyek menjadi 15 hari lebih cepat, selain itu biaya yang dikeluarkan akibat percepatan proyek menjadi lebih hemat hingga Rp22.215.000,-. [7].

Penelitian lainnya yaitu Optimalisasi dengan Metode PERT dan CPM pada pelaksanaan Proyek Twin Tower Building Pascasarjana Undip. Pada penelitian ini menggunakan metode PERT dan CPM untuk menganalisis jaringan kerja sehingga upaya percepatan durasi proyek dapat dilakukan dengan mempercepat kegiatan-kegiatan yang masuk pada jalur lintasan kritis [8].

Metode PERT dan CPM pernah juga dilakukan dalam penelitian pengaruh dari metode tersebut terhadap efektivitas dan efisiensi perusahaan furnitur "Dallas". CPM dan PERT sangat mengurangi waktu penyelesaian proyek di mebel company Dallas. Pada akhir penelitian, hasilnya diharapkan dapat membantu semua individu maupun individu perusahaan untuk lebih memahami konsep metode CPM dan PERT dalam mereduksi waktu penyelesaian proyek dan biaya. Ternyata, seperti yang diharapkan, hasil akhir dan kuantitatif menunjukkan pentingnya menerapkan metode tersebut dalam perencanaan, penjadwalan, dan mengendalikan suatu proyek dalam hal memberikan efektivitas dan efisiensi perusahaan mebel [9].

Peneliti dari negara Ghana menerapkan metode ini untuk menanggulangi kebanyakan proyek di Ghana yang saat ini menghadapi biaya dan waktu over-run yang meningkat seiring dengan meningkatnya kompleksitas proyek yang terlibat di negara tersebut. Hasilnya, dengan analisis menggunakan PERT dan CPM, keterlambatan proyek dapat dihindari dengan percepatan waktu hingga 39 hari dari waktu yang diharapkan namun berimbas pada pengeluaran yang meningkat antara $\mathrm{GH} \nless 57,156.35$ sampai GHф59,043.57 [10].

Penelitian berikutnya adalah pembuatan Aplikasi Penjadwalan Proyek dan Analisis Biaya Menggunakan PERT dan CPM. Pada penelitian ini membahas Metode Crashing untuk meminimalkan biaya yang dibutuhkan sambil mencapai waktu penyelesaian yang ditentukan. Crashing adalah mengurangi waktu proyek dengan mengeluarkan sumber daya tambahan. Dan di penelitian ini menggunakan analisis jaringan CPM/ PERT untuk menentukan biaya dan waktu optimal. Dengan analisis jaringan CPM/PERT didapatkan durasi normal proyek adalah 41 minggu dan biaya yang sesuai adalah Rs.1,27.500/-, durasi optimum proyek adalah 30 minggu dan biaya yang sesuai adalah Rs.1,23,400/-, Durasi minimum proyek adalah 25 minggu dan biaya yang sesuai adalah Rs.1,32,500/-,. Sehingga jaringan waktu yang digunakan pada langkah penelitian ini semuanya mengalami percepatan. Dan peneliti melihat bahwa semua aktivitas di jalur kritis yang bisa jatuh sesuai kondisi yang ada memungkinkan untuk mempercepat jaringan proyek [11].

Dari beberapa hasil penelitian di atas didapatkan kesimpulan metode CPM dan PERT dapat digunakan dalam optimalisasi, perencanaan dan penjadwalan sebuah proyek. Namun, metode PERT digunakan untuk menentukan suatu proyek yang belum diketahui secara pasti waktu penyelesaiannya, sedangkan metode CPM digunakan untuk membandingkan waktu penyelesaian suatu proyek yang sudah diketahui waktu penyelesaiannya berdasarkan pengalaman atau data jadwal waktu yang telah dibuat oleh perusahaan dan metode CPM dapat digunakan juga untuk penentuan jalur kritis di dalam perencanaan dan penjadwalan proyek. Terdapat kesamaan antara penelitian yang dilakukan dengan penelitian-penelitian yang telah dipaparkan di atas, yaitu digunakannya metode CPM. Perbedaannya adalah penelitian terdahulu belum mengimplementasikan metode ke dalam sistem informasi yang semakin mempermudah seorang project manager dalam menentukan jalur kritis, di samping perbedaan kasus yang diteliti.

\section{b. Manajemen Risiko}

Manajemen risiko adalah suatu aktivitas pengelolaan terhadap risiko yang berpotensi muncul pada suatu proyek, 
dapat dengan menggunakan metode dan peralatanperalatan tertentu. Manajemen risiko menyediakan lingkungan yang ditopang berbagai ilmu pengetahuan sehingga secara proaktif membuat keputusan untuk:

1) Terus-menerus menilai (memperkirakan) kesalahan (risiko) apa yang terjadi atas proyek.

2) Menentukan risiko-risiko penting yang harus digauli (dihadapi).

3) Mengimplementasikan strategi menggauli (menghadapi) risiko [12].

\section{c. Jalur Kritis}

Jalur kritis adalah rangkaian kegiatan atau pekerjaan kritis yang terdapat pada suatu proyek. Dalam penjadwalan proyek selain umur proyek jalur kritis merupakan suatu hal yang perlu diperhatikan dan dimonitor dengan baik, karena jalur kritis akan berpengaruh terhadap terlambat atau tidaknya suatu proyek. Manajer proyek harus memberikan perhatian lebih intensif kepada kegiatan yang berada pada lintasan itu dibandingkan dengan kegiatan yang lain [13].

\section{d. Metode PERT}

Teknik metode PERT (Program Evaluation Revien Technique) adalah suatu metode yang digunakan dalam evaluasi suatu proyek yang bertujuan untuk mengurangi sebanyak mungkin adanya penundaan, konflik, maupun gangguan terhadap kegiatan suatu proyek, termasuk di dalamnya melakukan koordinasi dan sinkronisasi dengan berbagai bagian dari keseluruhan pekerjaan agar dapat dilakukan percepatan terhadap penyelesaian suatu proyek. Metode ini melakukan penyusunan jadwal dan anggaran dari suatu pekerjaan di awal sebelum dilaksanakannya suatu proyek sehingga aktifitas pekerjaan dapat terkendali dan lebih teratur[14].

Keberhasilan dengan menggunakan teknik PERT dapat menghemat waktu penyelesaian proyek dua tahun lebih cepat dari jadwal yang direncanakan, sehingga metode ini banyak digunakan pada proyek-proyek besar, khususnya pada proyek-proyek riset dan penelitian di mana proyek-proyek tersebut belum pernah dilakukan dan tidak mempunyai data penyelesaian yang pasti [14].

Pada teknik PERT, dikenal 3 waktu penyelesaian kegiatan, yaitu waktu optimis (O), waktu paling mungkin (M) dan waktu pesimis (P). Pada setiap kegiatan waktu yang diharapkan adalah waktu rata-rata penyelesaian kegiatan.

\section{e. Metode CPM}

Metode CPM adalah suatu metode atau cara dan tahapan yang digunakan dalam perencanaan dan pengendalian dengan menggunakan prinsip pembentukan jaringan di mana metode ini cukup banyak digunakan pada pengelolaan suatu proyek. Metode CPM, memastikan jumlah waktu yang dibutuhkan untuk menyelesaikan berbagai tahap suatu proyek sudah diketahui pada awal sebelum pengerjaan, termasuk waktu yang dibutuhkan untuk menyelesaikan proyek serta hubungan antara sumber yang digunakan. Metode CPM memberikan hasil analisis pada jaringan kegiatan suatu proyek berupa optimasi biaya total proyek dengan cara mempersingkat waktu total penyelesaian proyek yang dilaksanakan [15].

Dalam proses identifikasi jalur kritis, hal yang pertama dilakukan adalah perhitungan mundur (backward pass) dan menghitung perhitungan maju (forward pass). Perhitungan maju (forward pass) dalam metode PERT dan CPM dilakukan untuk dapat menghitung waktu selesai paling awal dari suatu pekerjaan (EF), waktu mulai tercepat terjadinya suatu pekerjaan (ES) dan saat paling cepat dimulainya suatu pekerjaan (E), diawali dari Start (initial event) hingga Finish (terminal event). Sedangkan perhitungan mundur (backward pass) dilakukan untuk mendapatkan perhitungan waktu penyelesaian paling lambat suatu pekerjaan (LF), waktu paling lambat terjadinya suatu pekerjaan (LS) dan saat paling lambat dimulainya suatu pekerjaan (L), dimulai dari Finish hingga Start. Setelah selesai melakukan perhitungan maju dan perhitungan mundur, berikutnya yang harus dilakukan adalah perhitungan kelonggaran waktu (float) slack) dari aktivitas yang terdiri atas total float dan free float. Apabila suatu kegiatan tidak mempunyai kelonggaran atau dengan kata lain $\mathrm{S}=\mathrm{SF}=0$ maka aktivitas tersebut disebut kegiatan kritis. Kegiatan-kegiatan kritis ini akan membentuk lintasan kritis yang biasanya dimulai dari start (initial event) sampai finish (terminal event). Oleh karena itu, lintasan kritis inilah yang perlu dikendalikan [13].

Metode CPM digunakan untuk menentukan waktu kapan suatu kegiatan dimulai dan berakhir pada suatu proyek dalam analisis jaringan kerja, sehingga didapatkan waktu yang optimal untuk dapat menyelesaikan sebuah proyek.

\section{f. Perbedaan Metode CPM dan PERT}

Metode PERT dan CPM memiliki perbedaan sebagai berikut:

1) Penerapan metode, metode PERT digunakan pada perencanaan dan pengendalian proyek yang belum pernah dikerjakan sebelumnya, adapun metode CPM penggunaannya untuk melakukan penjadwalan dan pengendalian aktivitas yang sudah pernah dikerjakan sebelumnya sehingga waktu, data, serta biaya setiap unsur kegiatan telah diketahui lebih dulu oleh evaluator.

2) Waktu pengerjaan, metode PERT menggunakan tiga jenis waktu pengerjaan yaitu yang tercepat, terlama serta terlayak, adapun pada metode CPM hanya terdiri dari satu jenis informasi waktu pengerjaan saja, yaitu waktu yang paling tepat dan layak untuk menyelesaikan suatu proyek.

3) Fokus metode, pada metode PERT yang fokus ditekankan adalah pada faktor ketepatan waktu, karena menurut metode ini dengan memangkas waktu maka berdampak pada menurunnya biaya proyek, sedangkan pada metode CPM focus yang ditekankan adalah pada ketepatan biaya proyek rencana dengan realisasi.

4) Pada metode PERT anak panah menunjukkan tata urutan (hubungan presidentil) sedangkan pada CPM tanda panah adalah kegiatan [13]. 


\section{Metode}

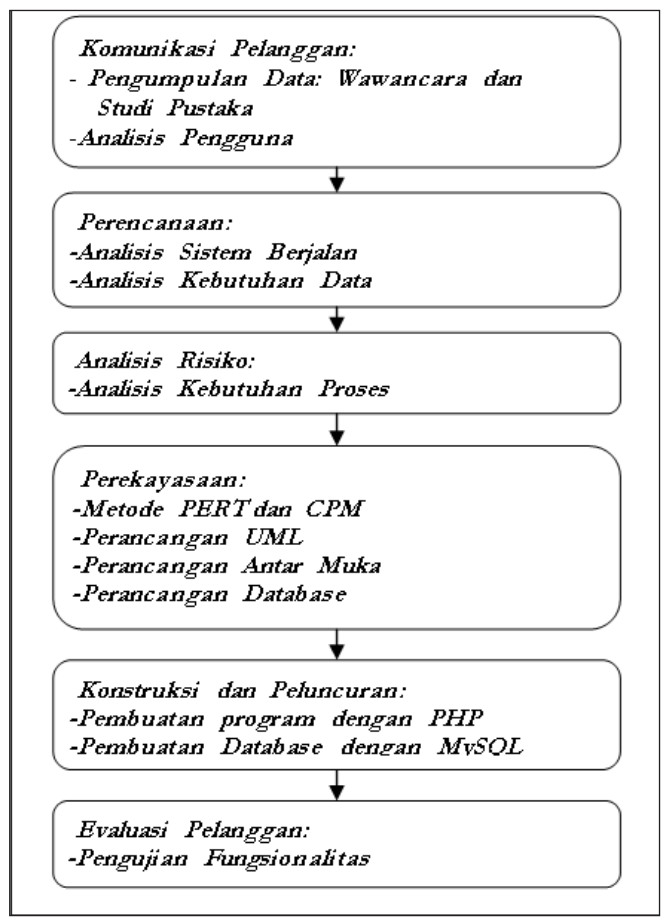

Gambar 1. Tahapan penelitian metode SDLC spiral

Tabel 1. Data kegiatan insialisasi dan predecessor

\begin{tabular}{cclcc}
\hline No. & Inisialisasi & \multicolumn{1}{c}{ Nama Kegiatan } & Pedecessor & Durasi \\
\hline 1 & A & Tracabilty \& Marking & G & 10 \\
2 & B & First Cutting & A & 30 \\
3 & C & Fabrication Keel Block & A & 34 \\
4 & D & Keel Laying & - & 43 \\
5 & E & Fabrication All Block & D & 38 \\
6 & F & Erection Block & G & 15 \\
7 & G & Fabrication Engine & - & 12 \\
8 & H & Fabrication Piping & F & 37 \\
9 & I & Installation Piping & F & 16 \\
10 & J & Connection Piping & H, I & 1 \\
11 & K & All Equipment Installation & J, L & 5 \\
12 & L & Cable Pulling, Termination & H, I & 55 \\
13 & M & MSB. ESB, atc Installation & K & 26 \\
14 & N & Engine Installation & F & 7 \\
15 & O & Engine Allignment & K & 3 \\
16 & P & Shaft Installation & & 28 \\
\hline
\end{tabular}

Dari berbagai masalah dalam mengerjakan proyek pada pembangunan kapal banyak terjadi keterlambatan dalam proses pengerjaannya. Dikarenakan selama ini perusahaan hanya menentukan jadwal berdasarkan pengalaman saja, sehingga tidak diketahui kegiatan kritis dalam kegiatan pengerjaan proyek. Oleh sebab itu, perlu diberikan solusi dengan pendekatan yang berbasis komputer yaitu membangun aplikasi manajemen risiko dengan penerapan metode PERT dan CPM pada aplikasi tersebut. Dalam penelitian ini, beberapa kajian untuk mendapatkan data dilakukan berupa wawancara dan studi pustaka. Adapun wawancara dilakukan dengan manager proyek untuk mendapatkan informasi mengenai proyek yang sedang dikerjakan dan pengambilan data kegiatan yang terdapat dalam proyek pembangunan kapal. 
Tabel 2. Tabel perkiraan waktu estimasi

\begin{tabular}{|c|c|c|c|c|}
\hline No. & Kegiatan & Waktu Optimis (ta) & Waktu Realistis (tm) & Waktu Pesimis (tb) \\
\hline A & Tracabilty \& Marking & 7 hari & 10 hari & 16 hari \\
\hline B & First Cutting & 27 hari & 30 hari & 45 hari \\
\hline C & Fabrication Keel Block & 28 hari & 34 hari & 60 hari \\
\hline $\mathrm{D}$ & Keel Laying & 35 hari & 43 hari & 50 hari \\
\hline $\mathrm{E}$ & Fabrication All Block & 28 hari & 38 hari & 52 hari \\
\hline $\mathrm{F}$ & Erection Block & 10 hari & 15 hari & 21 hari \\
\hline G & Fabrication Engine & 8 hari & 12 hari & 30 hari \\
\hline $\mathrm{H}$ & Fabrication Piping & 21 hari & 37 hari & 49 hari \\
\hline I & Installation Piping & 12 hari & 16 hari & 25 hari \\
\hline$J$ & Connection Piping & 1 hari & 1 hari & 7 hari \\
\hline K & All Equipment Installation & 3 hari & 5 hari & 31 hari \\
\hline $\mathrm{L}$ & Cable Pulling, Termination & 42 hari & 55 hari & 65 hari \\
\hline M & MSB. ESB, atc Installation & 21 hari & 26 hari & 35 hari \\
\hline $\mathrm{N}$ & Engine Installation & 5 hari & 7 hari & 14 hari \\
\hline
\end{tabular}

Data yang telah didapatkan tersebut diidentifikasi mana yang menjadi kegiatan sebelumnya dan menggambarkan diagram jaringan dari kegiatan-kegiatan tersebut. Dari diagram jaringan dapat dilakukan perhitungan untuk mendapatkan nilai ES, EF, LS, LF. Setelah mendapatkan nilai tersebut untuk selanjutnya melakukan perhitungan total slack untuk mendapatkan mana kegiatan yang merupakan kegiatan kritis. Pada perhitungan PERT terdapat perhitungan estimasi waktu atau waktu perkiraan (TE), variansi kegiatan jalur kritis, standart variansi proyek, dan menghitung probabilitas atau kemungkinan proyek dapat diselesaikan dalam batas waktu.

Tabel 1 merupakan kegiatan-kegiatan yang dilakukan dalam melaksanakan proyek pembangunan kapal secara general, yang menjadi data rujukan awal dalam pengolahan menggunakan metode PERT dan CPM, data di atas diambil dari PT. Bandar Abadi yang menjadi obyek penelitian.

\section{a. Metode PERT}

Tahapan pada metode PERT adalah sebagai berikut:

1. Melakukan inisialisasi kegiatan dan predecessornya, hasil digramnya diperlihatkan oleh gambar 2 .

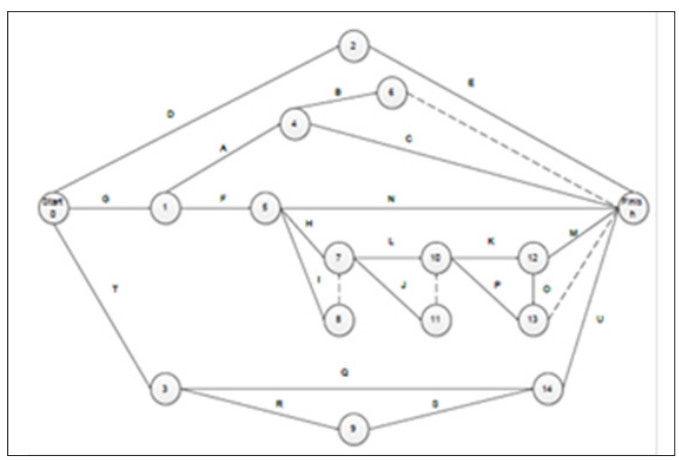

Gambar 2. Hasil tahapan penelitian berbasis SDLC spiral

2. Selanjutnya konsep probabititas dengan memberikan perkiraan rentang waktu yang lebih besar pada tiga elemen yaitu, angka estimasi untuk suatu kegiatan, waktu optimis, waktu realistis dan waktu pesimis.
Untuk waktu realistis durasi yang digunakan adalah durasi yang ada pada data tabel 2.

3. Dilanjutkan dengan menghitung waktu estimasi (TE) dengan rumus

$\mathrm{TE}_{(\mathrm{i})}=\frac{a+4 \cdot m+b}{6}$

te $=$ expected duration

$\mathrm{a}=$ waktu optimis

$\mathrm{m}=$ waktu realistis

$\mathrm{b}=$ waktu pesimis

4. Menghitung nilai 'Var' pada setiap pekerjaan dari keseluruhan yang didapat dari penggunaan rumus di bawah ini, yaitu:

$\operatorname{Var}(t e)=\mathrm{S}^{2}=\left[\frac{(t \dot{b}-t a)}{6}\right] \wedge 2$

$\operatorname{Var}($ te $)=$ Varians Kegiatan

$\mathrm{S} \quad=$ Deviasi Standar Kegiatan

$\mathrm{Tb}=$ Waktu Optimis

$\mathrm{Ta}=$ Waktu Pesimis

5. Menghitung perhitungan maju atau menghitung ES (Earliest Acitvity Start Time), karena S merupakan awal kejadian (start), maka waktu mulai tercepat ESstart $=0$

6. Menghitung perhitungan mundur atau menghitung LF (Latest Activity Finish Time), karena F merupakan akhir kegiatan besarnya waktu selesai terlama sama dengan waktu mulai tercepat, maka:

ESfinish $=150$, dikarenakan dari perhitungan maju hasil akhirnya adalah 150. Maka nilai tersebut menjadi nilai perhitungan awal untuk perhitungan mundur Sehingga $\mathrm{LF}(\mathrm{E})=\mathrm{LS}$ finish + waktu kegiatan $\mathrm{E}=$ $150-38=112$ Hari

7. Menghitung perhitungan slack atau kelonggaran waktu, menggunakan rumus :

$\mathrm{S}=\mathrm{LS}-\mathrm{ES}$

8. Menentukan apakah kegiatan tersebut jalur kritis atau tidak. Suatu kegiatan yang tidak mempunyai 
kelonggaran atau tidak boleh melebihi batas waktu (float) disebut kegiatan kritis. Dengan kata lain apabila total slack kegiatan tersebut sama dengan 0, maka kegiatan tersebut adalah kegiatan kritis. Kegiatan kritis yang didapatkan adalah : $\mathrm{G}-\mathrm{F}-\mathrm{H}-\mathrm{L}-\mathrm{K}$ $-\mathrm{M}$

9. Menghitung variansi proyek secara keseluruhan dengan menggunakan rumus:

$$
\operatorname{Var}=\sum \operatorname{var}
$$

10. Menghitung standar variansi proyek dengan rumus:

$$
\mathrm{Sd}=\sqrt{\text { variansi }}
$$

11. Menghitung nilai deviasi normal dengan rumus:

$$
\begin{aligned}
& \mathrm{Z}=[\text { batas waktu }(\mathrm{n}) \text { - waktu penyelesaian } \\
& \text { yang diharapkan] } / \mathrm{S}
\end{aligned}
$$

Setelah perhitungan yang dilakukan dengan menggunakan metode PERT maka didapatkan peluang 0,9826 yang artinya terdapat peluang sebesar 98,26\% untuk galangan menyelesaikan proyek tersebut dalam kurun waktu 150 hari atau kurang dari itu.

\section{b. Metode CPM}

Langkah selanjutnya adalah melakukan tahapan CPM. Berikut adalah beberapa cara dalam melakukan perhitungan dengan metode tersebut:

12. Menghitung perhitungan maju atau menghitung ES (Earliest Acitvity Start Time), karena S merupakan awal kejadian (start) maka waktu mulai tercepat ES1 $=0$.

13. Menghitung perhitungan mundur atau menghitung LF (Latest Activity Finish Time), karena F merupakan akhir kegiatan besarnya waktu selesai terlama sama dengan waktu mulai tercepat, maka:

Asumsi waktu kegiatan $\mathrm{F}=0$

$\mathrm{ES}_{\text {finish }}=150$, dikarenakan dari perhitungan maju hasil akhirnya adalah 150. Maka nilai tersebut menjadi nilai perhitungan awal untuk perhitungan mundur. Rumus yang digunakan adalah

$\mathrm{LF}(\mathrm{E})=\mathrm{LS}_{\text {finish }}+$ waktu kegiatan

Sehingga $\operatorname{LF}(\mathrm{E})=\mathrm{LS}_{\text {finish }}+$ waktu kegiatan $\mathrm{E}=150$ $38=112$ Hari.

14. Menghitung perhitungan slack atau kelonggaran waktu, menggunakan rumus:

$$
\mathrm{S}=\mathrm{LS}-\mathrm{ES}
$$

15. Menentukan apakah kegiatan tersebut jalur kritis atau tidak. Kegiatan kritis adalah: $\mathrm{G}-\mathrm{F}-\mathrm{H}-\mathrm{L}-\mathrm{K}-\mathrm{M}$ Sedangkan jalur kritis adalah: $1-5-7-10-12-$ finish event. Penentuan jalur kritis mengikuti kegiatan kritis yang didapatkan, dapat dilihat pada gambar 2 .
16. Menentukan waktu penyelesaian tercepat yaitu nilai akhir dari EF.

\section{c. Usecase}

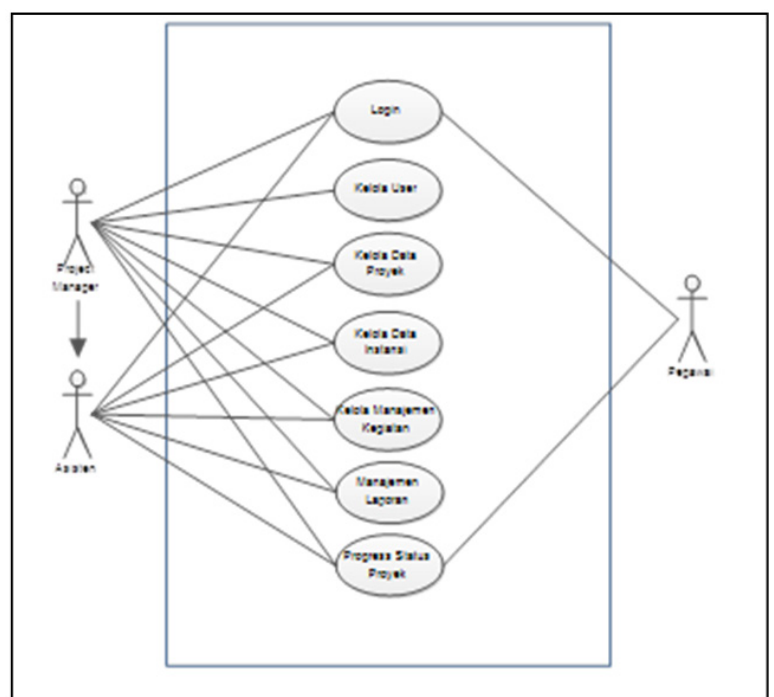

Gambar 3. Usecase aplikasi

Usecase diatas menggambarkan fungsionalitas yang dimiliki dari sistem informasi manajemen kapal di mana terdiri dari fitur login, kelola user, pengelolaan data proyek, pengelolaan data instansi, pengelolaan manajemen kegiatan, pengelolaan laporan, dan status proyek.

\section{d. Screenshoot Hasil}

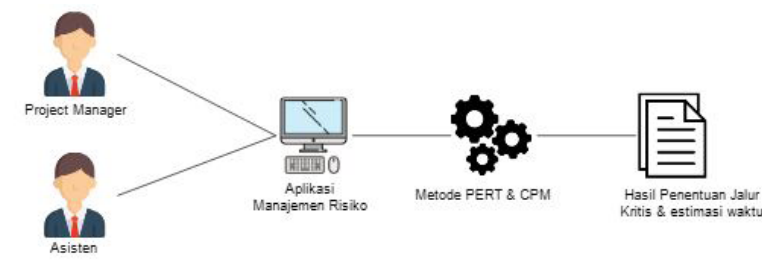

Gambar 4. Design arsitektur sistem

Gambar 4 menggambarkan tentang alur sistem yang digunakan. Personal yang dapat memanfaatkan perhitungan metode PERT dan CPM dalam sistem informasi ini hanya asisten dan manajer proyek saja.

\section{d. Rancangan Tabel}

Tabel 3. Struktur tabel user

\begin{tabular}{ccccc}
\hline No. & Field Name & Type & Size & Key \\
\hline 1. & ID_user & Smallint & 6 & PK \\
2. & Name & Text & & \\
3. & Username & Varchar & 30 & \\
4. & Password & Text & & \\
5. & Password_read & Varchar & 30 & \\
6. & Token & Text & & \\
7. & Id_level & Tinytint & 1 & \\
8. & Status & Tinytint & 1 & \\
\hline
\end{tabular}


Tabel 4. Struktur tabel instansi

\begin{tabular}{ccccc}
\hline No. & Field Name & Type & Size & Key \\
\hline 1. & Kode_instansi & Int & 2 & PK \\
2. & Nama_instansi & Varchar & 100 & \\
3. & Alamat_instansi & Varchar & 200 & \\
\hline
\end{tabular}

Tabel 5. Struktur tabel proyek

\begin{tabular}{ccccc}
\hline No. & Field Name & Type & Size & Key \\
\hline 1. & ID_proyek & Int & 4 & PK \\
2. & Nama_proyek & Varchar & 100 & \\
3. & Lokasi_proyek & Varchar & 100 & \\
4. & Waktu_proyek & Int & 4 & \\
5. & Biaya & Varchar & 100 & \\
6. & Keterangan & Varchar & 100 & \\
7. & Status & Tinytint & 1 & \\
\hline
\end{tabular}

Tabel 6. Struktur tabel kegiatan

\begin{tabular}{ccccc}
\hline No. & Field Name & Type & Size & Key \\
\hline 1. & ID_Kegiatan & Varchar & 100 & PK \\
2. & Nama_kegiatan & Text & & \\
\hline
\end{tabular}

\begin{tabular}{ccccc}
\hline \multicolumn{5}{c}{ Tabel } \\
7. Struktur tabel kegiatan mendahului \\
\hline No. & Field Name & Type & Size & Key \\
\hline 1. & ID_Proyek & Int & 11 & FK \\
2. & ID_Kegiatan & Varchar & 4 & FK \\
3. & ID_Kegiatan_dahulu & Varchar & 4 & \\
\hline
\end{tabular}

Tabel 8. Struktur tabel sub kegiatan

\begin{tabular}{ccccc}
\hline No. & Field Name & Type & Size & Key \\
\hline 1. & ID_Sub_Kegiatan & Varchar & 100 & PK \\
2. & Nama_sub_kegiatan & Text & & \\
\hline
\end{tabular}

Tabel 9. Struktur tabel proyek

\begin{tabular}{ccccc}
\hline No. & Field Name & Type & Size & Key \\
\hline 1. & ID_Level & Tinytint & 1 & PK \\
2. & Level & Tinytext & & \\
\hline
\end{tabular}

\begin{tabular}{ccccc}
\hline \multicolumn{4}{c}{ Tabel 10. Struktur tabel normal } \\
\hline No. & Field Name & Type & Size & Key \\
\hline 1. & $\mathrm{Z}$ & Float & & \\
2. & Prob & Float & & \\
\hline
\end{tabular}

Tabel 11. Tabel kegiatan proses

\begin{tabular}{ccccc}
\hline \multicolumn{5}{c}{ Tabel 11. Tabel kegiatan proses } \\
\hline No. & Field Name & Type & Size & Key \\
\hline 2. & ID_proyek & Int & 11 & FK \\
3. & ID_kegiatan & Varchar & 4 & FK \\
4. & Nama_kegiatan & Varchar & 50 & \\
5. & Lama_kegiatan & Int & 4 & \\
\hline
\end{tabular}

\begin{tabular}{|c|c|c|c|c|}
\hline No. & Field Name & Type & Size & Key \\
\hline 6. & Cepat_kegiatan & Int & 4 & \\
\hline 7. & Kegiatan_ES & Int & 11 & \\
\hline 8. & Kegiatan_LS & Int & 11 & \\
\hline 9 & Kegiatan_EF & Int & 11 & \\
\hline 10. & Kegiatan_LF & Int & 11 & \\
\hline 11. & Kegiatan_estimasi & Int & 11 & \\
\hline 12. & Kegiatan_biaya_normal & Int & 11 & \\
\hline 13. & Kegiatan_biaya_cepat & Int & 11 & \\
\hline 14. & Kegiatan_biaya_tambahan & Int & 11 & \\
\hline 15. & Tgl_awal & Date & & \\
\hline 16. & Tgl_akhir & Date & & \\
\hline 17. & ID_sub_kegiatan & Varchar & 100 & \\
\hline
\end{tabular}

\section{Hasil dan Pembahasan}

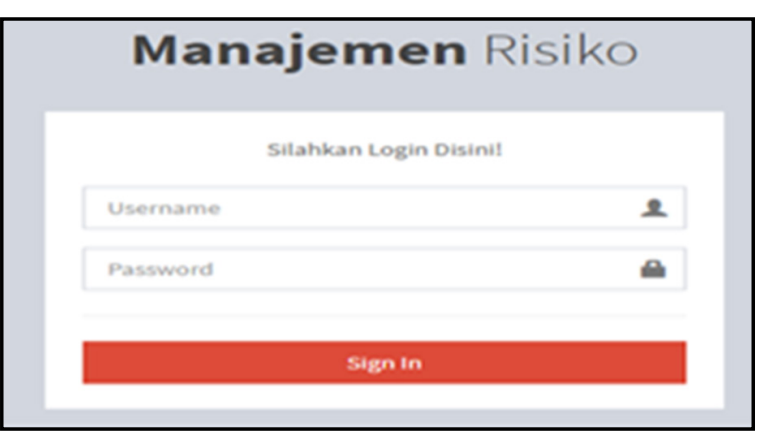

Gambar 5. Tampilan login

Gambar 5 merupakan tampilan login. Proses login dilakukan dengan cara memasukkan username dan password yang dimiliki pengguna. Pengguna yang dapat login adalah yang telah didaftarkan oleh super admin.

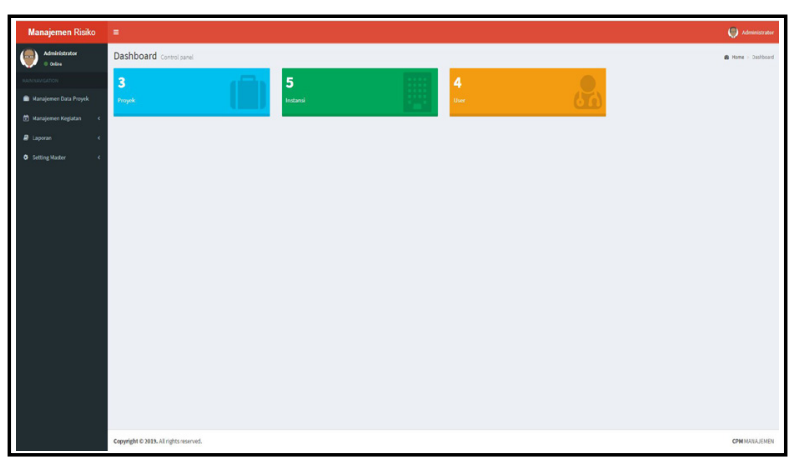

Gambar 6. Tampilan halaman muka

Gambar 6 merupakan halaman muka saat aplikasi dibuka atau dijalankan. Halaman muka menampilkan 3 pilihan menu yaitu proyek, instansi, dan pengguna. Pada bagian sebelah kiri juga terdapat pilihan menu yaitu manajemen data proyek, manajemen kegiatan dan setting master. 


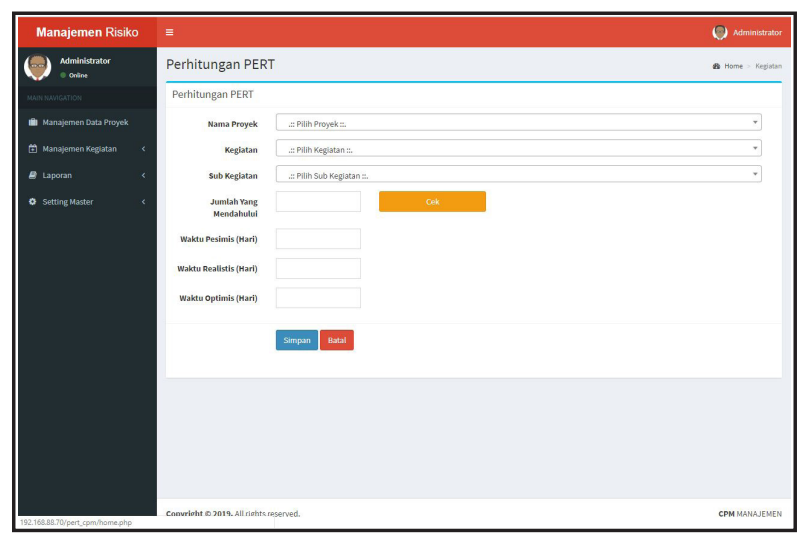

Gambar 7. Tampilan halaman input manajemen kegiatan perhitungan PERT

Gambar 7 merupakan halaman input manajemen kegiatan perhitungan PERT. Pada halaman tersebut terdapat inputan untuk melakukan perhitungan PERT yaitu: nama proyek, kegiatan, sub kegiatan, jumlah yang didahului, tombol cek untuk menampilkan field kegiatan yang mendahului, waktu pesimis, waktu realistis, dan waktu optimis. Setelah semua di-input kemudian klik tombol save. Maka data tersebut akan otomatis tersimpan di database.

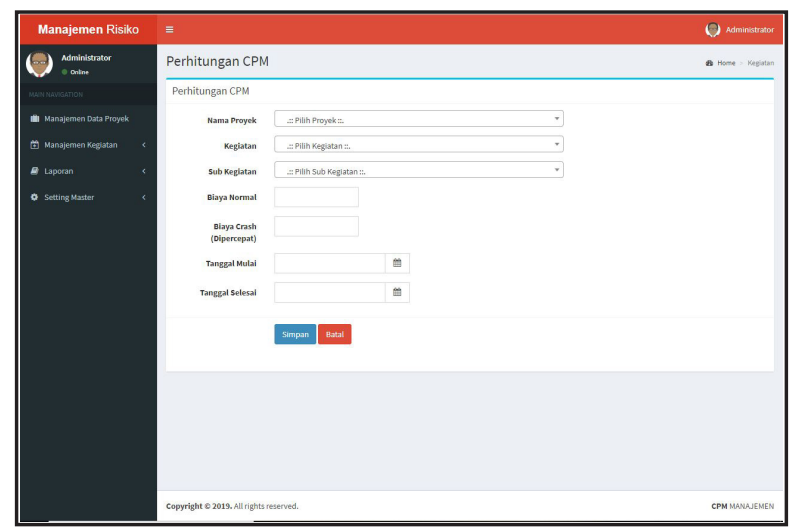

Gambar 8. Tampilan halaman input manajemen kegiatan perhitungan CPM

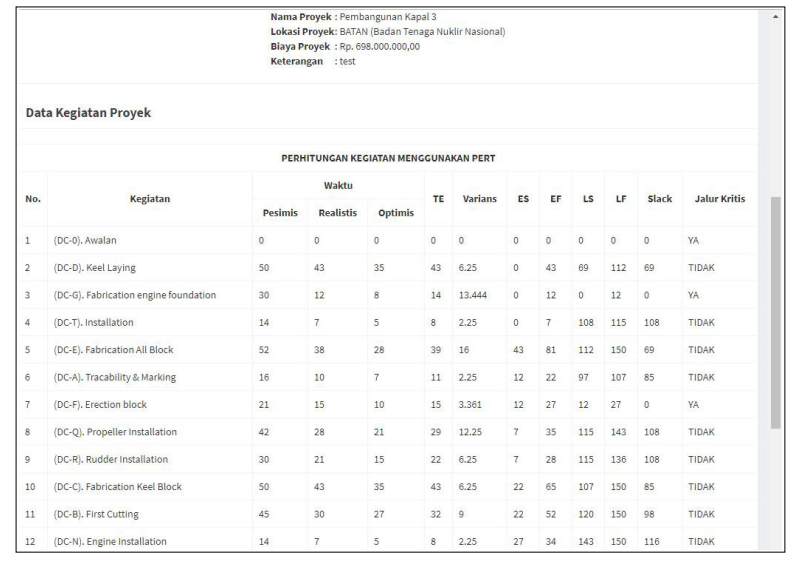

Gambar 9. Tampilan halaman hasil perhitungan PERT

Gambar 8 merupakan halaman input manajemen kegiatan perhitungan CPM. Pada halaman tersebut terdapat inputan untuk melakukan perhitungan CPM yaitu: Nama proyek, sub kegiatan, biaya normal, biaya dipercepat, tanggal mulai, dan tanggal selesai. Setelah semua di-input kemudian klik tombol save. Maka data tersebut akan otomatis tersimpan di database.

Gambar 9 merupakan tabel hasil perhitungan PERT. Tabel tersebut menampilkan hasil perhitungan dari inputan PERT yang telah di-imput sebelumnya. Dari tabel tersebut dapat diketahui kegiatan yang merupakan kegiatan kritis dan kegiatan yang bukan kegiatan kritis. Apabila slack kegiatan bernilai 0 maka kegiatan tersebut termasuk kedalam kegiatan kritis, tetapi apabila kegiatan tersebut tidak bernilai 0 maka kegiatan tersebut bukan kegiatan kritis.

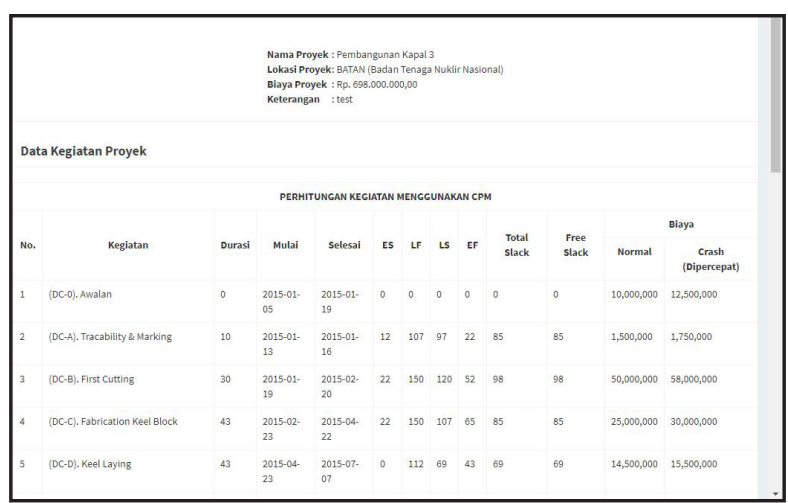

Gambar 10. Tampilan halaman hasil perhitungan CPM

Gambar 10 merupakan tabel hasil perhitungan CPM. Tabel tersebut menampilkan hasil perhitungan dari inputan CPM yang telah di-input sebelumnya. Dari tabel tersebut dapat diketahui biaya normal dari kegiatan dan biaya kegiatan dipercepat. Di dalam CPM menampilkan mana kegiatan kritis dan mana yang bukan.

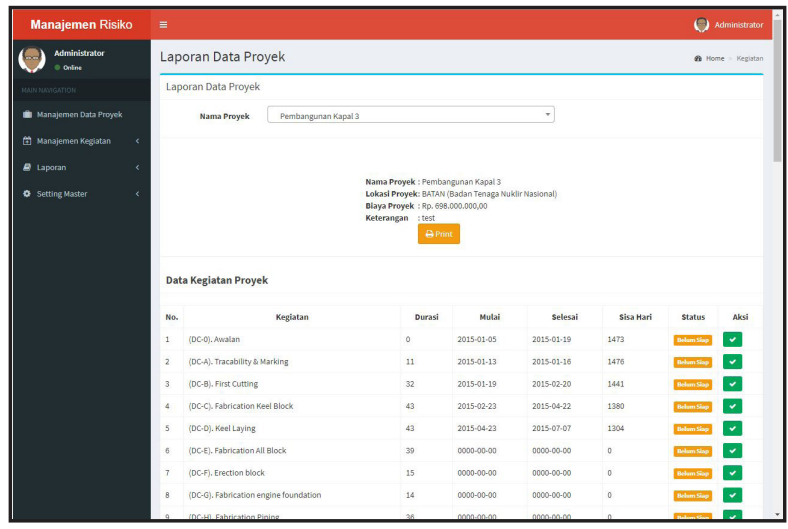

Gambar 11. Tampilan halaman laporan progress proyek

Gambar 11 merupakan tampilan laporan progress proyek yang sedang dikerjakan. Pada tabel tersebut menampilkan progress dan status dari proyek tersebut.

Dengan diimplementasikan metode PERT dan CPM pada suatu sistem informasi, memberikan kemudahan di mana seorang manajer proyek tidak perlu menghitung ulang setiap terjadi percepatan atau perlambatan waktu pengerjaan proyek karena sistem informasi akan menghitung dengan sendirinya, ditambah seorang manajer proyek dimudahkan untuk memonitor pekerjaan-pekerjaan apa saja yang sedang berjalan, akan berjalan, kegiatan yang sesuai jadwal, kegiatan yang mengalami keterlambatan, serta berapa biaya yang sudah dikeluarkan, sehingga manajer proyek dapat dengan cepat 
mengambil suatu tindakan untuk menjaga agar proyek yang ditanganinya tetap sesuai dengan waktu dan biaya yang dianggarkan.

\section{Kesimpulan}

Setelah melakukan penelitian dimulai dari tahap awal hingga proses pengujian maka didapatkanlah hasil berupa Aplikasi Manajemen Risiko mendapatkan bahwa jalur kritis yang perlu diperhatikan adalah kegiatan: $\mathrm{G}-\mathrm{F}-\mathrm{H}-$ $\mathrm{L}-\mathrm{K}-\mathrm{M}$. Selain itu penerapan metode PERT dan CPM pada penentuan jalur kritis pada proyek pembangunan kapal ini diketahui apabila total slack pada sebuah kegiatan bernilai 0, jika sebuah kegiatan tidak bernilai 0 maka kegiatan tersebut tidak termasuk ke dalam kegiatan kritis. Total slack ini didapatkan dari perhitungan maju dan mundur.

Pencapaian estimasi waktu pada sebuah proyek dengan metode PERT didapatkan dengan melihat probabilitas peluang penyelesaian pada tabel normal, sedangkan pada perhitungan CPM didapatkan dengan menghitung perhitungan maju.

Metode PERT dan CPM yang diimplementasikan ke dalam sistem informasi manajemen proyek pembangunan kapal mampu membantu manajer proyek pada PT. Bandar Abadi dalam memonitor kegiatan pembangunan kapal dengan memperkirakan waktu penyelesaian proyek dengan menggunakan sistem yang telah dibuat. Sistem mampu secara otomatis memetakan jalur kritis, mengidentifikasi awal dan akhir waktu setiap kegiatan untuk mencari jadwal proyek, dan menghitung jumlah waktu slack untuk setiap kegiatan sehingga dapat meminimalisasi terjadinya keterlambatan proyek dan dapat meminimalisasi biayabiaya yang ditimbulkan akibat keterlambatan pengerjaan proyek.

Untuk kasus pembangunan kapal ukuran menengah seperti pada kasus serupa, setelah didapatkan jalur kritis dan dilakukan perhitungan maka penyelesaian proyek kapal 98.26\% dapat diselesaikan dalam waktu 150 hari dalam kondisi optimis sehingga kecil kemungkinan terjadi kemunduran waktu proyek dibandingkan dengan sebelum adanya sistem informasi manajemen proyek pembangunan kapal.

\section{Daftar Pustaka}

[1] I. Dipohusodo, Manajemen Proyek dan Konstruksi, 2nd ed. Yogyakarta: Kanisius Yogyakarta, 1996.

[2] R. HA, Aplikasi TI dalam Manajemen Konstruksi, 1st ed. Sleman: deepublish, 2014.
[3] R. Kurniawan, "Studi Keterlambatan Proyek Pembangunan Kapal Kargo dengan Metode Bow Tie Analysis," Sepuluh Nopember Institute of Technology, 2015.

[4] D. Taurusyanti and M. F. Lesmana, "Optimalisasi Penjadwalan Proyek Jembatan Girder Guna Mencapai Efektivitas Penyelesaian dengan Metode PERT dan CPM Pada Pt Buana Masa Metalindo," J. Ilm. Manaj. Fak. Ekon., vol. 1, no. 1, pp. 32-36, 2015.

[5] E. Wiratmani and G. Prawitasari, "Penerapan Metode Jalur Kritis dalam Penyusunan Jadwal Pelaksanaan Proyek Pembangunan Fasilitas Rumah Karyawan," Factor Exacta, vol. 6, no. 3, pp. 210-217, 2013.

[6] L. Krajewski, L. P. Ritzman, and M. K. Malhotra, Operation Management. New Jersey: Pearson, 2010.

[7] Sugiyarto, S. Qomariyah, and F. Hamzah, "Analisis Network Planning dengan CPM (Critical Path Method)," MATRIKS Tek. Sipil, vol. 1, no. 4, pp. 408-416, 2013.

[8] E. Dannyanti, "Optimalisasi Pelaksanaan Proyek dengan Metode PERT dan CPM (Studi Kasus Twin Tower Building Pascasarjana Undip)," Universitas Diponegoro, 2010.

[9] A. Göksu and S. Ćatović, "Implementation of Critical Path Method and Project Evaluation and Review Technique," 3rd Int. Symp. Sustain. Dev., pp. 205-212, 2012.

[10] W. Agyei, "Project Planning and Scheduling Using PERT and CPM Techniques with Linear Programming: Case Study," Int. J. Sci. Technol. Res., vol. 4, no. 8, pp. 222-227, 2015.

[11] S. Chatwal, "Application of Project Scheduling in a Bottling Unit Startup Using PERT and CPM Techniques," Int. J. Adv. Res. Eng. Appl. Sci., vol. 3, no. 6, pp. 1-9, 2014.

[12] H. Siahaan, Manajemen Risiko pada Perusahaan dan Birokrasi, 2nd ed. Jakarta: PT. Elex Media Komputindo, 2009.

[13] E. Herjanto, Manajemen Operasi, 3rd ed. Jakarta: Grasindo, 2008.

[14] E. Irwansyah, Sistem Informasi Geografis : Prinsip Dasar dan Pengembangan Aplikasi, 1 st ed. Yogyakarta: Digibooks, 2013.

[15] H. Zaharuddin, Menggali Potensi Wirausaha, 2nd ed. Bekasi: CV Dian Anugrah Prakasa, 2006. 